PAEDAGOGIA ChristianA

$1 / 25$ (2010) - ISSN 1505-6872

Maria Braun-Gałkowska*

Lublin

\title{
Dialog w rodzinie
}

Dialog można rozumieć jako komunikację między osobami lub grupami osób, w której partnerzy dążą do wzajemnego zrozumienia, co powoduje zbliżenie między nimi i umożliwia współdziałanie ${ }^{1}$. W rodzinie może to być np. dialog małżeński, czyli rozmowa jaką członkowie Domowego Kościoła Ruchu „Światło Zycie” organizują specjalnie co jakiś czas, by usunąć wszystko, co zagraża jedności małżeńskiej ${ }^{2}$, lub narada rodzinna w ważnej sprawie. Można też mówić o dialogu w szerszym znaczeniu, polegającym na komunikacji między członkami rodziny, toczącej się codziennie poprzez krótką wymianę zdań przy różnych okazjach. Taki dialog, czyli po prostu rozmowa, ma dla rodziny zasadnicze znaczenie.

Rodzina jest, a przynajmniej powinna być, wspólnotą czyli komunią, a komunia wymaga komunikacji. Dlatego mówiąc o dialogu i komunikacji rodzinnej, trzeba przede wszystkim podkreślić znaczenie tego, żeby członkowie rodziny ze sobą rozmawiali. Ponieważ do rodziny należy parę osób, miedzy którymi istnieje cała sieć relacji, określa się ją obecnie jako system interakcji. Można wiec opisywać komunikację i warunki jej powodzenia z punktu widzenia interakcji między dwoma osobami (np. w małżeństwie, między rodzicem a dzieckiem, babcią a wnukiem itd.), a także z punktu widzenia rodziny jako całości. Prawidłowa komunikacja rodzinna zwiększa spójność rodziny, która bywa zagrożona przez nadmierne korzystanie

* Prof. dr hab. Maria Braun-Gałkowska, kierownik Katedry Psychologii Wychowawczej i Rodziny w Instytucie Psychologii Wydziału Nauk Społecznych Katolickiego Uniwersytetu Lubelskiego Jana Pawła II, członek Polskiego Towarzystwa Psychologicznego i International Academy of Family Psychology.

${ }^{1}$ J. Tarnowski, Jak wychowywać?, Warszawa 1993, s. 116.

${ }^{2}$ C. Opalach, Wspólnota religijna a funkcjonowanie rodziny, Olsztyn 2006, s. 21. 
z mediów, umożliwia załatwianie spraw bieżących, unikanie niepotrzebnych konfliktów, przekaz wartości i zwiększa bliskość rodzinną, a zarazem stanowi wzór porozumiewania się dla dzieci.

\section{Rodzina jako grupa rozmawiająca}

W socjologii i psychologii istnieją różne definicje małych grup, czyli zespołów ludzi związanych wspólnym celem i wzajemnymi relacjami, w przeciwieństwie do przypadkowych zbiorów. Na użytek tego tekstu wystarczy wymienić jedną charakterystyczną cechę małej grupy: rozmowę. To ona zbiór obcych ludzi przemienia w grupę. Na przykład, parę osób siedzących w przedziale kolejowym nie stanowi grupy, ale stają się nią, gdy zainteresowane jakąśs sprawą zaczną rozmawiać ze sobą. Wtedy każda osoba nabiera swoistego znaczenia, choćby takiego, że po wyjściu jednej z nich, inne odczuwają jej nieobecność.

Nie każde posługiwanie się mową jest rozmową. Nie jest nią rozkaz wydany podwładnemu, jak w wojsku; nie jest nią informowanie, jak przez redaktora telewizyjnego, choćby kokieteryjnie mówił o rozmowie ze słuchaczami; nie jest nią krótkie zamówienie skierowane do kelnera. Rozmowa wymaga wzajemnego kontaktu, wzajemnego słuchania i wymiany myśli.

Rodzina była dawniej rozpatrywana przede wszystkim jako środowisko wychowawcze i analizowano wpływ rodziców na dzieci, biorąc pod uwagę głównie ten jeden kierunek oddziaływania ${ }^{3}$. Te ujęcia nawiązywały do psychoanalizy, która podkreślała znaczenie pierwszych doświadczeń dziecka w rodzinie dla późniejszego życia jednostki, a także związane były z pedagogiką. $Z$ czasem przedmiotem analiz stały się relacje rodzinne, w których oddziaływanie jest wzajemne, zarówno jeśli chodzi o związek między mężem i żoną ${ }^{4}$, między rodzicami a dziećmi ${ }^{5}$, a także ze starszym pokoleniem ${ }^{6}$.

Współczesne podejście do rodziny charakteryzuje się nie tylko analizą wzajemnych interakcji poszczególnych członków rodziny, ale ujmowaniem człowieka jako uczestnika grupy rodzinnej, przy czym rodzina traktowana jest jako struktura czy też system wzajemnych interakcji ${ }^{7}$. W takim ujęciu analizuje się nie tylko wzajemne oddziaływanie wszystkich członków rodzi-

\footnotetext{
${ }^{3}$ S. Baley, Psychologia wychowawcza w zarysie, Warszawa 1960.

${ }^{4}$ M. Braun-Gałkowska, Miłość aktywna, Warszawa 1980; J. Rostowski, Zarys psychologii malżeństwa, Warszawa 1987.

${ }^{5}$ J. Rembowski, Więzi uczuciowe w rodzinie, Warszawa 1972.

${ }^{6}$ L. Dyczewski, Więź międzypokoleniowa w rodzinie, Lublin 2002.

${ }^{7}$ M. Radochoński, Psychoterapia rodzinna w ujęciu systemowym, Rzeszów 1984; J. Rembowski, Rodzina w świetle psychologii, Warszawa 1986; M. Braun-Gałkowska, Psy-
} 
ny (np. wpływ matki na dziecko), ale działanie całego systemu, w którym każda osoba zależy od wszystkich pozostałych osób (np. dziecko zależy od matki, ojca i brata), a także od wszystkich pozostałych relacji (np. relacja między matką a dzieckiem zależy od jakości związku między rodzicami).

W każdym systemie wyróżnić można podsystemy i każdy członek rodziny może być członkiem różnych podsystemów (np. podsystem małżeński: mąż-żona, rodzicielski: matka-córka, braterski: dziecko-dziecko itd.). To, co dzieje się wewnątrz podsystemu i sposób porozumiewania się miedzy jego członkami, ma wpływ nie tylko na osoby go tworzące i nie tylko od nich zależy, ale także oddziałuje na innych członków rodziny oraz interakcje w innych podsystemach, a równocześnie jest od nich uzależnione. Zależności te działają na zasadzie sprzężeń zwrotnych i obejmują cały system rodzinny ${ }^{8}$.

System tworzy całość charakteryzującą się cechami takimi, jakich nie mają jej poszczególne elementy, podobnie jak kombinacja tlenu i wodoru daje substancję nową: wodę, której właściwości są inne niż właściwości wodoru i tlenu ujmowane osobno ${ }^{9}$. Żeby opisać rodzinę trzeba poznać wszystkie osoby należące do niej, zmiany zachodzące w tych osobach, interakcje między tymi osobami i zmiany zachodzące w tych interakcjach. Liczbę interakcji w rodzinie można obliczyć, posługując się prostym wzorem: $\mathrm{X}=\left(\mathrm{Y}^{2}-\mathrm{Y}\right):$, gdzie $\mathrm{X}$ oznacza ilość interakcji, a Y - ilość osób. Tak więc W małżeństwie bez dzieci jest tylko jedna interakcja (miedzy małżonkami), w rodzinie z jednym dzieckiem - trzy, ale już z trojgiem dzieci jest ich dziesięć. Rodziny nie można scharakteryzować przez dodawanie cech poszczególnych osób, ale przez ich wzajemny układ. Każda z osób należących do rodziny oddziałuje nie tylko na interakcję, w której bezpośrednio uczestniczy, np. żona ma wpływ na interakcję małżeńska, ale także na wszystkie inne interakcje, np. na to, jaki jest kontakt między jej mężem a dzieckiem, teściowa ma wpływ na relację małżeńską synowej, kontakt zięcia z wnukiem itd. Tak więc rodzina to nie tylko osoby, ale także to, co dzieje się między tymi osobami, a zwłaszcza komunikacja między nimi.

Takich interakcji w rodzinie kilkuosobowej jest kilkadziesiąt. One to, wszystkie razem, tworzą wewnętrzne życie rodziny. I wszystko to, co się członkom rodziny udaje lub nie udaje, dotyczy nie tylko ich samych, ale także wszystkich pozostałych osób. Tak więc, gdy komunikacja między rodzicami jest udana, jest to sytuacja korzystna także dla dzieci, a gdy są skłó-

chologiczna analiza systemów rodzinnych osób zadowolonych i niezadowolonych z matżeństwa, Lublin 1992.

8 I. Namysłowska, Terapia rodzin, Warszawa 1997.

9 G. Salem, L 'approche therapeutique de la famille, Paris 1987. 
ceni - dziecko traci poczucie bezpieczeństwa, a jego zachowanie zmienia się na niekorzyść. Dzieje się tak dlatego, że dla dziecka rodzice są podstawą życia w sensie i fizycznym, i psychologicznym. $Z$ drugiej strony, gdy jedno $\mathrm{z}$ rodziców nie umie się porozumieć $\mathrm{z}$ dzieckiem, ma to wpływ na relację małżeńską (z drugim rodzicem) i powoduje kłótnie miedzy nimi, zły kontakt między żoną a teściową ma wpływ na relację miedzy mężem a żoną itd.

Choć więc komunikację w rodzinie można opisywać z punktu widzenia poszczególnych par porozumiewających się, trzeba pamiętać, że każda z nich wpływa na wszystkie pozostałe. Rodzina stanowi małą grupę społeczną, jeżeli ze sobą rozmawia, ale mimo wielości wspólnych spraw, nie jest wolna od niebezpieczeństwa zmieniania się w zbiór podobny do osób obcych, niezainteresowanych sobą, które przypadkowo znalazły się obok siebie, a nawet wrogich. Rodzina przestaje ze sobą rozmawiać nie tylko w tzw. ciche dni, kiedy małżonkowie starają się wzajemnie ukarać milczeniem, stwarzając sytuację szczególnie niebezpieczną dla swego szczęścia małżeńskiego. Rodzina przestaje też rozmawiać, gdy rodzice w stosunku do dzieci ograniczają się do wydawania poleceń, nie znajdując czasu na słuchanie i gdy dzieci zajęte Internetem nie interesują się rodzicami. Przestaje rozmawiać, gdy wymienia tylko bieżące informacje dotyczące spraw organizacyjnych, typu: „Wrócę późno”, „Masło w lodówce”. Nie rozmawia też siedząc obok siebie w półmroku i w milczeniu wpatrzona w telewizor.

Im więcej jest takich sytuacji, im mniej rozmowy, tym bardziej rodzina zmienia się z grupy społecznej w ludzi obcych, a dom coraz bardziej przypomina hotel. Przeciwnie - rozmowa zwiększa spójność rodziny, pogłębia wzajemny związek jej członków, daje poczucie bliskości i bezpieczeństwa. Niestety, na rozmowy często brak czasu i miejsca, a wreszcie - wskutek odzwyczajenia się - brak wspólnych tematów. Mieszkania bywają nadmiernie zagęszczone i hałaśliwe, a wszyscy spieszą się do pracy, do szkoły, na różne zajęcia dodatkowe, które odbywają się dla każdego z członków rodziny w innych godzinach. Każdy ma swoje sprawy i poczucie, że jeśli oderwie się od nich nawet na krótko, nie nadrobi straconych chwil. Wydaje się więc, że nie ma gdzie i kiedy rozmawiać, a w końcu nie ma i o czym, bo jest to sytuacja typowa, że gdy spotka się kogoś po długim niewidzeniu, nie wiadomo od czego zaczaćc. Jeżeli jednak znaczenie rozmowy docenia się, można wszystko jakoś zorganizować, ale wymaga to świadomego starania.

Rodziny różnią się między sobą pod względem jakości komunikacji ${ }^{10}$. Jeśli komunikacja jest prawidłowa, to rozmowy są częste, sprawiają przyjemność, w rodzinie wzrasta wzajemne poznanie się osób, które interesują się sobą wzajemnie, coraz więcej wiedzą o sobie i dowiadują się o wy-

${ }^{10}$ R. Mucchielli, Psychologie de la vie conjugale, Paris 1973. 
darzeniach i zmianach, jakie u innych zachodzą. Przy takiej komunikacji, komunikaty słowne i bezsłowne są zgodne, to znaczy że gesty, mowa ciała i ton głosu mają to samo znaczenie co wypowiadane słowa, a komunikaty słowne nie są jedyne, bo uzupełniają je uśmiechy, przytulenia, prezenciki, sms-y itd.

W rodzinie o komunikacji nieprawidłowej rozmowy są rzadkie, a gdy już do nich dojdzie, to są męczące i zużywają dużo energii, co z kolei zwiększa tendencje do ich unikania. Wzajemne poznanie nie zwiększa się więc wówczas, a przeciwnie, nawet zmniejsza, bo każdy człowiek się zmienia i wiadomości nieaktualne stają się bezwartościowe. W takiej sytuacji członkowie rodziny nie wiedzą o sobie wzajemnie, co robia, co lubia, jakich maja przyjaciół i nie interesują się tym. Komunikaty słowne i bezsłowne są często sprzeczne (np. wypowiedziane znudzonym tonem zapewnienie o zainteresowaniu omawianą sprawa), co wprowadza dezorientację i zniechęcenie.

\section{Klucze udanej komunikacji}

W rodzinie, ze względu na częstość i trwałość kontaktów, jest rzeczą niemożliwą niekomunikowanie się całkowite, $\mathrm{z}$ tym, że milczenie, a nawet częsta nieobecność, też jest rodzajem komunikatu, bo może wyrażać obojętność lub niechęć. Komunikacja nie może być udana, jeżeli ludzie nie rozmawiają ze sobą, nie poświęcają sobie czasu. Tym, co wyróżnia komunikację w rodzinie od wszelkich innych, jest jej wielkie nasycenie emocjonalne. Rozmowy z osobami spoza rodziny można uniknąć, w rodzinie kontakt bywa nieudany, ale jest nieunikniony, a ponieważ dotyczy osób bliskich sobie, ma wielkie znaczenie uczuciowe: pozytywne lub negatywne - zależnie od jakości porozumiewania się. Ostre słowa usłyszane od osoby obcej są oczywiście niemiłe, ale od osoby bliskiej mogą być bardzo raniące, natomiast nawet drobne dowody zainteresowania od osoby emocjonalnie znaczącej są bardzo cenne.

Żeby komunikacja była udana, to dwie osoby muszą przede wszystkim ze sobą rozmawiać, ale dobra komunikacja powinna też spełniać podstawowe warunki, które najczęściej określane są jako otwartość i empatia ${ }^{11}$. Aby rozmowa była udana, powinna w niej być otwartość, szczerość, przeźroczystość. Jeżeli ktoś chce wywołać określone zachowanie drugiej osoby manipulując nią, a nie mówiąc wprost, o co mu chodzi, uniemożliwia prawdziwą komunikację. Potrzebne jest więc jasne wyrażanie swoich przeżyć, a po drugie: trafne, można by powiedzieć - troskliwe, odbieranie sygnałów

${ }^{11}$ B. Harwas-Napierała, Komunikacja interpersonalna w rodzinie, Poznań 2008. 
od partnera interakcji. Oczywiście, jakość komunikacji zależy od obu stron. Cechy dobrej komunikacji dotyczą każdego jednocześnie, bo wielokrotnie, w czasie jednej rozmowy, trzeba być jednocześnie przeźroczystym przy mówieniu i empatycznym przy słuchaniu. Komunikacja polega nie tylko na jednostronnym nadawaniu, ale również na odbieraniu informacji i sprawdzaniu, czy zrozumiało się ją prawidłowo.

Już w momencie ,nadawania” informacji zdarza się zakłócenie komunikacji. Często rozmówcy ukrywają swoje intencje, chcąc w ten sposób osiągnąc jakieś pozytywne rezultaty, ale w ten sposób uniemożliwiają ,odbiorcy" zrozumienie swoich intencji i ustosunkowanie się do nich, a tym samym uniemożliwiają dialog. Warunkiem dobrej komunikacji jest otwartość intencji i zgodność informacji słownych z bezsłownymi.

Szczerość jest nieraz mylnie rozumiana. Otwartość nie polega na wygłaszaniu opinii o drugim, ale na ujawnianiu własnych uczuć. W psychologii komunikacji określa się to jako komunikaty „typu ja”. Komunikat „typu ty” (np. „Twoje zachowanie jest niekulturalne”) zawiera ocenę i często rani, natomiast komunikat „typu ja” (np. „Twoje zachowanie sprawia mi przykrość") nie obraża, ale pokazuje skutki postępowania.

Otwartość jednej strony dialogu zwiększa otwartość drugiej, ale stanowi pewne ryzyko, bo może zostać wykorzystana na szkodę osoby ujawniającej się, dlatego wymaga zaufania, które z kolei oparte jest na wzajemnej wierności, uczciwości i dobrej woli obu stron. To ujawnianie siebie, polegające na zgodności tego, co się mówi, z tym, co się przeżywa, pokazaniu się takim, jakim się jest, ujawnieniu tego, co się odczuwa i czego oczekuje - nazywa się w psychologii otwartością lub przeźroczystością. To jeden z kluczy do dobrej komunikacji.

Drugim kluczem jest empatia, pomagająca we właściwym zrozumieniu tego, co się odbiera i wczuwaniu się w rzeczywiste intencje tego, z kim się rozmawia. Udana komunikacja musi być empatyczna, to znaczy, że należy słuchać tego, co drugi mówi, słuchać i starać się zrozumieć. Trzeba mieć cierpliwość słuchania i starać się o zrozumienie istoty tego, co ktoś mówi. Są ludzie, którzy starają się zawsze przypisać rozmówcy złe intencje, zamiast starać się dobrze go zrozumieć, postawić w jego położeniu, spojrzeć na sprawę z jego punktu widzenia.

Ten moment komunikacji też często bywa zakłócany, bo nieraz własne domysły myli się z faktycznym stanem rzeczy. Interpretowanie intencji partnera rozmowy zależy w dużej mierze od własnych doświadczeń i nastroju chwili, trzeba więc kontrolować, czy jest ono prawidłowe. Dla upewnienia się, czy dobrze zrozumiało się drugiego, potrzebne jest uzyskiwanie tzw. informacji zwrotnych, czyli pytanie o to , czy „odbiór” jest prawidłowy. Dobra komunikacja jest podstawowym warunkiem udanego życia seksualnego, 
a także bardzo ważnym czynnikiem szczęścia w małżeństwie. Małżonkowie w związkach nieszczęśliwych nie są spontaniczni w wyrażaniu swoich myśli, mówią aluzjami, a część spraw ukrywają, co powoduje u drugiej strony reakcje obronne i na zasadzie sprzężenia zwrotnego pogłębia nieszczerość. Umiejętność dobrej komunikacji warunkuje też dobry kontakt między rodzicami a dziećmi, właściwie można powiedzieć, że jest jego podstawą. Jest dla prawidłowego wychowania warunkiem koniecznym, choć niewystarczającym, bo w wychowaniu ważny jest nie tylko kontakt, ale wartości będące jego celem.

Umiejętności szczerego komunikowania swoich uczuć (komunikaty „typu ja”) zamiast oceniania, a także zrozumienia emocji i potrzeb drugiej osoby, pozwalają uniknąć wielu niepotrzebnych konfliktów. Jednocześnie, umiejętność rozwiązywania konfliktów (zamiast ich podsycania lub tłumienia) pomaga w dobrych kontaktach międzyludzkich. Liczne badania psychologiczne ukazują silny związek miedzy prawidłową komunikacją a jakością relacji małżeńskiej oraz rodzicielskiej ${ }^{12}$.

Wymienione pokrótce warunki dobrej komunikacji można określić jako wymogi formalne. Bardzo ważna jest też treść komunikatów. Najczęściej popełniane pod tym względem błędy to komunikacja raniąca lub nudna. Wypowiadanie komunikatów raniących, zwłaszcza wśród osób bliskich, np. od ojca do dziecka, staje się przyczyną wielkiego cierpienia i niejednokrotnie źródłem trwałych urazów. Natomiast wypowiedzi powtarzane rozwlekle i wielokrotnie powodują unikanie kontaktu przez osobę, do której są kierowane.

Jednocześnie powierzchowne zwiększenie wiedzy na temat komunikacji i znaczenia jasności komunikatów staje się czasem przyczyną nieliczenia się ze znaczeniem wypowiadanych słów. Dążenie do tego, by nie tłumić swoich uczuć i spontanicznie je wyrażać, prowadzić może do używania zwrotów bardzo ostrych i trudnych do zapomnienia. Niekontrolowane odreagowanie emocji, może być dla „odbiorcy” tak przykre, że niszczące relacje na długi czas.

Jakość komunikacji w rodzinie pochodzenia staje się wzorem sposobu porozumiewania się dla dzieci, które w sposób spontaniczny naśladują zachowania, które widzą w rodzinie, np. manipulacyjne i nieszczere odnoszenie się matki do ojca staje się wzorem odnoszenia kobiet do mężczyzn. Używanie obraźliwych epitetów i ocenianie drugiego (komunikaty „typu ty”)

${ }^{12}$ M. Plopa, Więzi w matżeństwie i rodzinie, Kraków 2005; T. Rostowska, Małżeństwo, rodzina, praca a jakość życia, Kraków 2008; M. Kaźmierczak, Empatia jako czynnik podnoszacy jakość komunikacji interpersonalnej, w: Człowiek u progu trzeciego tysiaclecia, Kraków 2005, s. 561-572. 
uczą takiego sposobu wypowiadania się i bywają w przyszłości przenoszone do własnej rodziny prokreacyjnej.

Na szczęście dobre komunikowanie się jest umiejętnością wyuczalną. Można się jej uczyć podczas warsztatów psychologicznych, na kursach przedmałżeńskich i na uniwersytetach dla rodziców, a także z książek. Obecnie jest bardzo dużo publikacji na temat dialogu, komunikacji i rozmowy ${ }^{13}$. Bardzo ważne jest poznanie reguł udanego porozumiewania się i rzeczywiście stanowi pomoc, oczywiście pod warunkiem ich stosowania.

W systemie rodzinnym komunikacja dotyczy często spraw życiowo doniosłych i powodujących silne przeżycia emocjonalnie. Dodatkową trudnością jest to, że rozmowa często ma miejsce w różnych podsystemach równocześnie (np. między mężem, żoną i matką żony), co stwarza sytuację bardziej zawiłą niż przy komunikacji dwóch osób. Zachowanie reguł, nawet poznanych i teoretycznie przyjętych, jest więc bardzo trudne. Gdy rozmowie towarzyszy duże napięcie emocjonalne, wynikające z siły związków miedzy osobami i wagi problemów, często dochodzi do zdenerwowania i postępowania wbrew przemyślanym zasadom. Wtedy, po uspokojeniu się, trzeba rozmowę zaczać od nowa, stosując kolejne zasady: przebaczenia i pojednania ${ }^{14}$. Gdy Piotr zapytał, ile razy trzeba przebaczać: „ «Czy aż siedem razy?» Jezus mu odrzekł: «Nie mówię ci, że aż siedem razy, lecz aż siedemdziesiąt siedem razy»" (Mt 18, 21-22).

\section{Komunikacja rodzinna a media}

System rodzinny można scharakteryzować z różnych punktów widzenia, opisując cechy, których nie można przypisać poszczególnym jego członkom, ale dotyczące rodziny jako całości. Jedną z ważnych cech rodziny jest jej spójność, oznaczająca wzajemne więzi emocjonalne rodziny. Spójność jest ważną cechą oznaczającą wzajemne emocjonalne powiązanie rodziny, które może mieć różny stopień: od spójności za małej (niezaangażowanie), poprzez umiarkowaną, do za dużej (splątanie) ${ }^{15}$.

Członkowie rodziny o niskiej spójności wzajemnie nie interesują się sobą i niewiele o sobie wiedzą, nie współdziałają ze sobą i nie udzielają sobie pomocy. Można powiedzieć, że żyją nie tyle ze sobą, co obok siebie. Każdy zajęty jest swoimi sprawami, a łączy ich tylko wspólne mieszkanie, które jest raczej miejscem noclegu i realizowania własnych zajęć (,jak w hotelu"),

\footnotetext{
${ }^{13}$ F. Schulz von Thun, Sztuka Rozmawiania, Kraków 2007.

${ }^{14}$ M. Braun-Gałkowska, Psychologia domowa, Lublin 2008.

${ }^{15}$ D. H. Olson i in., Family Inventories, St. Paul 1985.
} 
niż wspólnego przebywania. Spójność może też być za wysoka. Prowadzi wówczas do zatarcia granic między członkami rodziny, uniemożliwia ich autonomię i utrudnia realizację własnych zadań rozwojowych (np. założenie własnej rodziny prokreacyjnej).

Umiarkowany stopień spójności jest dla wszystkich członków rodziny najbardziej korzystny. Sprzyja umacnianiu związku między małżonkami, umożliwia identyfikację dzieci z rodzicami przy jednoczesnym zachowaniu autonomii. Zapewnia poczucie bliskości i więzi emocjonalnych, wzajemną pomoc i umożliwia pomyślne rozwiązywanie konfliktów.

Stopień spójności może się zmieniać w czasie cyklu życia rodzinnego w kierunku wzrastającej lub malejącej spójności. Ponieważ jest cechą całej rodziny, zależy od wszystkich jej członków, a także od szerszego kontekstu społecznego. Wśród czynników wpływających na rodzinę z zewnątrz, jako szczególnie ważne, wymienić trzeba media elektroniczne. Rodzina, której członkowie poświęcają dużo czasu na media, tym samym ma mniej kontaktów wzajemnych, z drugiej strony, w tych rodzinach, w których nie ma silnych i bliskich więzi, media nabierają większego znaczenia. Związek ten ma charakter cyrkularny. Jeżeli stopień spójności rodziny jest niski, brak w niej bliskich kontaktów, a wszyscy są zainteresowani tylko swoimi sprawami, to nie można się dziwić, że uciekają z rodziny w świat medialny, a im więcej czasu wszyscy członkowie rodziny przeznaczają na korzystanie z mediów, tym niższy staje się stopień spójności.

Chociaż na pewno media nie są jedyną przyczyną niskiego poziomu spójności wielu rodzin, mają w nim jednak znaczący udział. Współcześnie mówi się już często o potrzebie edukacji medialnej i ochrony dzieci przed zbyt długim, prowadzącym niejednokrotnie do uzależnienia, korzystaniem z mediów, a także przed niektórymi treściami telewizji, gier komputerowych i Internetu, zwłaszcza obrazami agresji i pornografii. Treści te, jeśli pochłaniają dużo czasu, mają negatywny wpływ na psychikę, co zostało ukazane w licznych badaniach ${ }^{16}$. Natomiast najczęściej nie docenia się jeszcze wpływu mediów na rodzinę ujmowaną jako całość i całościowego reagowania rodziny na ten wpływ.

W okresie burzliwego rozpowszechniania się telewizji gromadziła ona rodziny $\mathrm{w}$ jednym pomieszczaniu, ale jednocześnie kontakty międzyosobowe ograniczała do komentarzy i uwag o programie. Przy wspólnym oglądaniu audycji członkowie rodziny znajdują się koło siebie, ale nie razem ze sobą. Obecnie w wielu domach jest więcej niż jeden odbiornik telewizyjny, a jednocześnie także komputer lub komputery. Programy są kierowane do określonych grup odbiorców i poszczególni członkowie rodziny w zależno-

${ }^{16}$ M. Braun-Gałkowska, I. Ulfik-Jaworska, Zabawa w zabijanie, Lublin 2002. 
ści od płci, wieku, poziomu wykształcenia i zainteresowań wybierają inne audycje. Rozpowszechnienie Internetu pogłębia to zjawisko. W domu można też do jednego komputera podłączać parę monitorów, a także posługiwać się łatwym do przenoszenia laptopem. Każdy korzysta z Internetu w taki sposób, jaki jest mu potrzebny i jaki mu odpowiada.

W sytuacji, w której każdy z członków rodziny korzysta ze swojego monitora, każdy może swobodnie realizować swoje zainteresowania i zaspokajać swoje potrzeby nie przeszkadzając innym, ale jednocześnie też nie kontaktując się z nimi. Członkowie rodziny coraz mniej czasu spędzają wspólnie, a nawet obok siebie, lecz każdy osobno zajęty jest swoimi programami i swoimi zainteresowaniami. Rodzina mało spójna nie może skutecznie przekazywać wartości i wizji świata, pozostawiając pustkę, w którą wchodzą treści nadawane przez media elektroniczne, które stały się istotną częścią środowiska społecznego. Dla członków rodziny ogranicza to okazję do wymiany informacji i wspólnego działania i - co za tym idzie - zmniejsza spójność grupy rodzinnej ${ }^{17}$.

Większość informacji pochodzi obecnie z przekazu medialnego, który staje się podstawowym pośrednikiem pomiędzy jednostką, a społeczeństwem - czy to lokalnym, czy globalnym. Tożsamość jednostki budowana jest $\mathrm{w}$ coraz mniejszym stopniu poprzez kontakt $\mathrm{z}$ najbliższym otoczeniem i oddziaływanie rodziców, członków rodziny oraz innych bliskich osób, a w coraz większym przez odlegle wydarzenia, osoby i wzory dostępne jedynie pośrednio. To, co jest dostępne bezpośrednio, staje się coraz mniej istotne, zarówno dla socjalizacji pierwotnej, jak i następującej w toku życia. Ponieważ rodzina daje mniej okazji do doświadczeń bezpośrednich, tym bardziej wzrasta znaczenie doświadczeń pośrednich. Doświadczenie społeczne jest obecnie głównie doświadczeniem zapośredniczonym.

Cechy doświadczenia zapośredniczonego to, według Giddensa ${ }^{18}$, przede wszystkim wtargnięcie odległych zdarzeń do sfery doświadczeń codziennych i efekt kolażu - chaotyczny melanż informacji, dźwięków oraz obrazów. Następuje przemieszanie tego, co lokalne i globalne, bliskie i dalekie, swojskie i obce. Sytuacja społeczna, w tym sytuacja, w której rozgrywał się proces socjalizacji, była zawsze umiejscowiona w jakiejś konkretnej przestrzeni fizycznej, rozgrywała się w jakimś „tutaj”. Obecnie nastapiło zaburzenie społecznego porządku przestrzeni, który długo wydawał się naturalny i jedyny.

${ }^{17}$ M. Braun-Gałkowska, Rodzina wśród mediów, w: T. Rostowska, A. Jarmołowska (red.), Rozwojowe $i$ wychowawcze aspekty życia rodzinnego, Warszawa 2010, s. 22-32.

${ }^{18}$ A. Giddens, Nowoczesność i tożsamość. „Ja” i społeczeństwo w epoce późnej nowoczesności, Warszawa 2001. 
Następstwem tego staje się odwrócenie porządków. Coraz częściej zdarza się, że swojskie i bliskie stają się zdarzenia czy osoby odległe w przestrzeni, lecz znane dzięki mediom. Bardziej realne wydaje się to, co jest doświadczane medialnie i pośrednio, niż osoby i sytuacje bezpośrednio towarzyszące życiu. Doświadczenie zapośredniczone rozprzęga tradycyjne związki i zmniejsza wagę tradycyjnych relacji społecznych, ale także tworzy związki nowe, bardziej uniwersalne.

Drugą cechą doświadczenia zapośredniczonego jest efekt kolażu, nadający zdarzeniom dochodzącym do odbiorcy formę mieszaniny, nieuporządkowanej mieszaniny informacji, obrazów i dźwięków pochodzących $\mathrm{z}$ bardzo wielu przypadkowych źródeł. Taka niespójna wizja świata pogłębia izolację, a zarazem powoduje niepokój.

Rodzina o małej spójności, niepowiązana przez częstą komunikację, staje się sumą odrębnych elementów, w której każdy jest sam, nie ma więc w rodzinie oparcia. Taka rodzina jest mało atrakcyjna i staje się mniej znacząca od obrazów medialnych, których percepcja zajmuje wiele czasu, a zarazem jest bardzo interesująca: pokazuje wydarzenia szybko się zmieniające, wciąż nowe i ciekawe. Doświadczenie zapośredniczone powoduje, że świat zewnętrzny staje się bardziej dostępny, ale zarazem budzi niepokój.

Jak widać przy pobieżnej obserwacji, a co potwierdzają szczegółowe analizy ${ }^{19}$, świat medialny zawiera bardzo dużo agresji i treści erotycznych, które są dla dziecka intrygujące, atrakcyjne i emocjonalnie pobudzające. Kolaż tych medialnych obrazów, choć fascynujący, nie ma cech spójności i trwałości, przez co budzi niepokój. Niepokoju tego nie łagodzi rodzina, bo ona stała się w codziennym przeżywaniu mniej ważna. Osoby odległe przestrzennie, z którymi ma się kontakt dzięki mediom, mogą mieć większe znaczenie niż te, z którymi się mieszka, a postacie fikcyjne z seriali czy gier komputerowych mogą stać się ważniejsze niż członkowie rodziny, z którymi mało się przebywa i nie współdziała na co dzień. Dzięki doświadczeniu zapośredniczonemu świat zewnętrzny w stosunku do rodziny stał się bliższy, ale zarazem bardziej niepokojący. Dziecko otrzymuje przez media, a zwłaszcza Internet, ogromną ilość informacji, ale są one bezładne i pomieszane, a rodzina tracąc swoją pozycję nie ma okazji do ich porządkowania.

Dla młodzieży kontakt z rówieśnikami, nawiązywany przez media elektroniczne, stwarza nowe możliwości wymiany myśli, zwierzania się i organizowania, przez co zwiększa naturalną i ważną w wieku dorastania tendencję do bliskości z grupami koleżeńskimi. Internet i telefony komórkowe umożliwiają liczne kontakty, ale najczęściej poza rodziną. Zwłaszcza młodzi ludzie żyją często raczej wśród mediów niż w rodzinie. Media zmie-

${ }^{19}$ A. Gała, I. Ulfik-Jaworska (red.), Czas pusty, Lublin 2006. 
niają więc styl życia rodzinnego i zmniejszają spójność grupy rodzinnej. Nie jest jednak tak, żeby rodziny były całkowicie bezbronne wobec tego wpływu, gdyż poddają mu się w różnym stopniu i bardzo różnią się między sobą, także pod względem sposobu korzystania z mediów. Rodziny, których członkowie spędzają razem więcej czasu i częściej rozmawiają a łączy ich komunikacja przyjemna i życzliwa, korzystają z mediów w sposób umiarkowany i prawidłowy. W rodzinach, w których nie ma silnych i bliskich więzi, w których komunikacja jest rzadka i męcząca, media nabierają za dużego znaczenia, pochłaniają zbyt dużo czasu i zastępują rozmowy bezpośrednie. W takiej sytuacji rodzina nie ma okazji do przekazu wartości i tradycji rodzinnych.

Tak więc choć media, z jednej strony, przez korzystanie nadmierne, doprowadzające nieraz do uzależnienia, powodują zmniejszenie spójności rodziny, to z drugiej strony, rodzina przez swoja prawidłową - czyli umiarkowaną spójność, może nie rezygnując z korzystania z mediów, korzystać $\mathrm{z}$ nich w sposób racjonalny.

$* * *$

Uświadomienie sobie znaczenia, jakie ma dla całej grupy rodzinnej prawidłowa komunikacja, mobilizować powinno do szczególnej o nią dbałości. Dbałość ta powinna się wyrażać przez staranie o prawidłową komunikację miedzy poszczególnymi osobami, a także przez organizowanie dla wszystkich członków rodziny atrakcyjnego sposobu wspólnego spędzania czasu, przez inicjowanie rozmów i zainteresowanie sprawami innych osób. Szczególną do tego okazją są wspólne posiłki, podczas których żadne media nie powinny być włączane. Podczas posiłków jedzonych osobno zwykle często oglądana jest telewizja lub korzysta się z Internetu, który można obsługiwać jedną ręka, przy skierowaniu wzroku na ekran. Jedzenie wspólne wyklucza to, a w każdym razie powinno wykluczać, a daje okazję do patrzenia na siebie, wzajemnego mówienia do siebie i słuchania. Okazją do rodzinnych rozmów są też wspólne spacery, załatwianie zakupów i wszelkie czynności wykonywane razem. Takich okazji jest - gdy się zastanowić - sporo.

Czasem jednak trzeba znaleźć na rozmowę czas specjalny, gdy uwaga niczym nie rozproszona koncentruje się, choćby na chwilę, wyłącznie na rozmówcy. Z dziećmi najlepiej się tak rozmawia, gdy leżą w łóżku, przed zaśnięciem. Ze współmałżonkiem dobrze jest też organizować taki czas specjalny, gdy w domu zrobi się cisza, bo dzieci już śpią. Taki czas potrzebny jest też, przynajmniej niekiedy, na rozmowę ze starszymi rodzicami, teściami, dziadkami, którzy nawet jeśli mieszkają wspólnie, nieraz - szczególnie jeśli nie dosłyszą - mają poczucie wyobcowania i o ważnych sprawach domowników dowiadują się przypadkiem. 
Rozmawiać warto nie tylko ze względu na wychowanie dzieci i powodzenie małżeństwa, ale także na kontakt każdego z każdym. Ważne są rozmowy intymne w cztery oczy, ale także całej grupy rodzinnej. Sprawy nabierają plastyczności i stają się ciekawe przez to, że widziane są inaczej przez dziadków, rodziców i wnuków, a to uzupełniające się spojrzenie jest cenne dla wszystkich członków rodziny i zwiększa ich wzajemną bliskość.

\section{Dialog in family \\ (Summary)}

Dialog can be understood as the communication between persons or the groups of persons which aim at the mutual understanding resulting in the strengthening of relations and in the fostering of cooperation. In case of a family it can be a consultation in the important matter but also in a broad sense it can be any other communication between the family members in everyday life situations. Such a dialog understood as the daily conversation have vital importance for a family.

Families are constituted by more than one person who create a network of relations thus by social sciences families are described as the interaction systems. Conditions of good communication can be described from the point of view of two persons as well as from the point of view of a family as an unit. Correct communication promotes family cohesion, allows to handle daily issues, helps to avoid conflicts, supports intergenerational transmission of values, increase the inner intimacy of family and can be the pattern for the younger generations. Correct communication depends on openness and empathy of family members and can be threaten by the overuse of media among other factors. 
